\title{
EFFECTS OF FORTIFIED AGAINST PAN BREAD WITH ASPARAGUS ON IMPAIRED KIONEY FUNCTION IN EXPERIMENTAL RATS
}

\author{
By \\ Rehab Ibrahim Tag Al Deen \\ Home Economics Dept., \\ Faculty of Specific Education, \\ Zagazig University .Egypt
}

Research Gournal Specific Fducation

Faculty of Specific Fducation

Mansoura University

ISSUE NO. 42, APRIL. 2016

مجلة بحوث التربية النوعية - جامعة المنصورة

العدد الثاني والأربعوز - أبريل البريل 
- Effects of Fortified Against Pan Bread with Asparagus on Impaired Kidney Function 


\section{EFFECTS OF FORTIFIED AGAINST PAN BREAD WITH ASPARAGUS ON IMPAIRED KIDNEY FUNCTION IN EXPERIMENTAL RATS}

Rehab Ibrahim Tag Al Deen*

Abstract

Thirty adult albino male rats, Sprague Dawley strain were randomly classified into fife groups (6 rats each). The first group kept as normal control fed standard diet only. The other fourth groups fed on basal diet containing $2 \%(\mathrm{~W} / \mathrm{W})$ arginine to induce renal failure for two weeks reclassified into positive control, pan bread fortified with 5\% asparagus, pan bread fortified with $10 \%$ asparagus, and pan bread fortified with 15\% asparagus groups.

This study aimed to investigate effect of asparagus with fortified pan bread on the levels of some biochemical parameters as kidneys function, liver function and lipid profile of chronic renal failure in rats. The present study investigated the effect of asparagus fortified pan bread 5\%,10\% and $15 \%$ ASP G. The results revealed significant decrease in uric acid, creatinine and urea nitrogen. The results revealed that decrease significant in AST, ALT and ALP levels compared with the positive control group. The results revealed that, the positive control group increase significant in TC, TG, LDL-c and VLDL-C. while showed significant decrease in serum glutathione, catalase and SOD. Pathological results of organs showed damage in them. In contrary, feeding rats on died containing asparagus especially at high level (10\%) revealed marked improvement of these parameters and histopathological.

\section{Introduction}

Bread is an Egyptian product that represents the main diet component for rich and poor Egyptian consumers. In Egypt, there is a big gap between wheat production and its consumption, where the total production of wheat grains covers only about $55 \%$ of the total needs, the

* Home Economics Dept., Faculty of Specific Education, Zagazig University .Egypt 
way to overcome this problem is to search for the native sources which could be used with wheat flour bread making (Litwinek et al., 2013). Nutritional value of bread mainly depends of type of flour used in breadmaking and application of other technological additives. Wheat flour, used in the production of bread, is usually characterized by a high carbohydrates and proteins, but this protein has a very low nutritional value, because it contains lower proportion of essential amino acids (Dewettinck et al., 2008).

Asparagus or garden asparagus, scientific name asparagus officinal is a spring vegetable a flowering perennial (Grubben et al., 2004) plant species in the genus Asparagus. It was once classified in the lily family, like its allium cousins, onions and garlic (Asparagus Officinalis, 2010, and Usda, et al., 2010). Asparagus is widely cultivated as a vegetable crop.

Asparagus in one of the most healthful foods on the planet. It leads nearly all fruits and vegetables in the wide array of nutrients it supplies. Ten ounces (one box of frozen spears) have only 68 calories and 9 grams of protein, and variety of minerals such as selenium, zinc, calcium, copper, and manganese. Plus, it is very rich in folate. (Gerald, 2008) .

Asparagus is a healthy and nutritious vegetable that is consumed in many countries. Historically, asparagus has been used as a traditional medicine in China as as an antifebrile and antitussive agent, hair growth stimulator, and diuretic agent (Shay, et al., 1997, Javed, et al., 2012, Kamalakkannan and Prince, 2006, and Panchal, et al., 2011). A recent study indicated that asparagus and its extracts have potential in terms of anti-fungal, anti-dyspeptic, antihypertensive, antidyslipidemic, and antihyperglycemic effects (Meda, et al., 2005, Bopana, et al., 2007, Tranchim, et al., 2010 and Carrasco, et al., 2012). However, the mechanisms of these effects have not been fully elucidated.

Various bioactive compounds, including flavonoids, sterol-saponins, oligosaccharides, and caroenoids, have been identified in asparagus. (Pothuang, et al., 2008, Kawano, et al., 2002, Ueno, et al., 2005 and Deli, et al., 2000). 
Several numbers of plants have been screened for contraceptive activities in an attempt to replace hormonal contraceptives. Some have shown promising activity (Farnsworth, et al., 1991). One of these plants is asparagus pubescens Bak (liliaceace). It has been reported that most contraceptive agents are in the liver through biochemical process of ring reduction, inactivation and conjugation $\mathrm{L}$ befor elimination either through the bile or the kidney. In addition, these agents are known to interfere with the integrity of the liver and kidney to varying degrees (Elias, 2011).

The roots of asparagus racemosus are bitter, sweet oleaginous, cooling, and indigestible, appetizer, and are useful in dysentery, tumors, inflammation, biliousness, leprosy, epilepsy, and night blindness. In unani system, the roots are used as laxatives, tonic, aphrodisiac, galactogoue, and in disease of kidney and liver (Negi, et al., 2010).

The aim of the present investigation was to improve the nutritional, healthy values and also, to evaluate the influence of pan bread fortified with asparagus on the levels of some physiological parameters as kidneys function, liver function and lipid profile of chronic renal failure in rats.

\section{Material and methods}

- Materials:

Arginine ${ }^{\circ}$ : Arginine was purchased from El-Gomhoreya Company, Cairo Egypt.

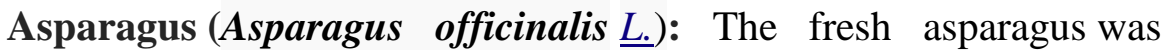
obtained from the local market, washed and cut into bits. The bits was sun dried for three (3 days), after which a mechanical grinder was used to grind the dried bits into powdered form and stored at room temperature $\left(25^{\circ} \mathrm{C}\right)$.

Ingredients for bread preparation: wheat flour, sugar, salt and yeast were purchased from the local market.

Rats: Thirty six male rats weighing $(100 \pm 5 \mathrm{~g})$ were used in this study purchased from Agricultural Research Center, Giza, Egypt. All animals were housed in plastic cages and kept under the same laboratory conditions of temperature $\left(25 \pm 2{ }^{\circ} \mathrm{C}\right)$ and lighting (12:12hr light: dark cycle), for one 
week prior to starting the experiments. The rats were provided ad libitum with tap water and fed with standard diet.

- Methods:

\section{Proximate composition:}

Asparagus powder was analyzed for moisture, fat, protein, ash, and crude fiber contents according to (A.O.A.C., 2002).

Normal pan bread was prepared as following (g \%):

pan bread prepared according to (Abdel Ghafor, et al., 2011) as follows, (90 g) flour, (1.5 g) yeast, (1.5 g) salt, (3 g) shortening, (3g) sugar, (1g) improver and variable water. All dry ingredients were weighed and placed in a mixer for $5 \mathrm{sec}$, and then a suspension of the yeast in water was added. The ingredients were mixed for 4 minutes at slow speed and for additional 6 minutes at fast speed .Water was added to the mixture as indicated by the farinograph results. The dough temperature was $28.9^{\circ}-$ $32.2^{\circ} \mathrm{C}$ following mixing. Dough was left to rest for $20 \mathrm{~min}$ at $28-30^{\circ} \mathrm{C}$ (first proofing) then transferred and scaled into $150 \mathrm{~g}$ pieces, rounded into balls by hand then placed in metal pans and let to ferment at the same temperature according to (A.A.C.C., 2005) for a final proof for $50 \mathrm{~min}$. When the height of dough had risen to about $1-2 \mathrm{~cm}$ above the pans, the pans were placed in an electric oven. Bread dough loaves were baked at $240{ }^{\circ} \mathrm{C}$ for $20-25 \mathrm{~min}$ .The resulted pan bread was allowed to cool at room temperature for $2 \mathrm{~h}$ before being packed in polyethylene bags and stored at room temperature for further analysis.

\section{Supplementation of pan bread:}

In this study, pan bread ingredients were altered by partially replacing the wheat flour by 5,10 and $15 \%$ of powdered dried asparagus.

\section{Chemical composition of dried pan bread:}

Moisture, crude protein, crude fat, ash and crude fiber contents were determined in pan bread, according to (A.O.A.C., 2000) while total carbohydrates content were calculated by difference 


\section{Sensory evaluation:}

Evaluations of the pan bread (fortified and un-fortified bread with asparagus) were carried out according to (Molander, 1960).

The biological assay: Thirty male albino rats (Sprague Dawleey strain) were kept in individual stainless steel cages under hygienic conditions and fed one week on basal diet for adaptation in ad libitum. The basal diet in the preliminary experiment consists of $20 \%$ casein (protein > $80 \%$ ), corn oil $4 \%$, cellulose $5 \%$, vitamin mixture $1 \%$, salt mixture $3.5 \%$, choline chloride $0.2 \%$ and the remainder is corn starch (Reeves, et al., 1993). Vitamin composition of diets prepared according to (A.O.A.C., 1975). After a period of adaptation on basal diet (one week), the rats were divided into two main groups, the first group ( $\mathrm{n}=6$ rats) fed on basal diet, as a normal control group, while the second group ( $\mathrm{n}=24$ rats) fed on basal diet containing $2 \%(\mathrm{~W} / \mathrm{W})$ arginine to induce renal failure for two weeks according to the method described by (Yokozawa, et al., 2003). Then, the second main group divided into three subgroups as follows:

- The first group: Fed on arginine diet containing half amount of protein from un-fortified pan bread (as a positive control group).

- The second group: Fed on arginine diet containing half amount of protein from ground dried pan bread fortified with 5\% ASPG.

- The third group: Fed on arginine diet containing half amount of protein from ground dried pan bread fortified with 10\% ASPG.

- The fourth group: Fed on arginine diet containing half amount of protein from ground dried pan bread fortified with 15\% ASPG.

During the experimental period (28 days), food intake and body weights, were recorded twice weekly. At the end of the experiment, the animals were fasted overnight, then the rats were anaesthetized and sacrificed, and blood samples were collected from the aorta.

\section{Biochemical analysis:}

Blood samples were taken and centrifuged (3000 rpm/15 min.) to obtain serum. Serum was used to estimate some biochemical parameters, i.e. serum uric acid, urea nitrogen and creatinine were determined by the 
methods of (Fossati, et al. 1980, Patton and Crouch, 1977, and Bohmer, 1971) respectively. Aspartate aminotransferase (AST) and alanine aminotransferase (ALT) were assayed by (Reitman and Frankel, 1957), while alkaline phosphatase (ALP) was assayed by (Kind and King, 1954). Serum total cholesterol, triacylglycerol, high density lipoprotein and low density lipoprotein were determined by the methods of (Roeschlau, et al. 1974, Fossati and Principe, 1982, Allian, et al., 1974 and Friedewald, et al., 1972) respectively, Kidneys were separated from each rat and weighted to calculate kidneys weight to body weight \%. Two kidneys of each rats were rapidly removed and perfuse with 50 to 100 of ice cold $0.9 \% \mathrm{NaCL}$ solution for estimation of superoxide dismutase (SOD), glutathione peroxidase (GPX), glutathione S-transferase (GST) and malondialdehyde (MDA) according to (Beuchamp and Fridovich, 1971,Weiss, et al ., 1980 , Ellman, 1958 and Uchiyama and Mihara, 1978) respectively.

\section{Histopathological examination:}

Kidney sections were taken from different rats in each group immediately after scarification. The tissues were washed with the normal saline solution to remove blood, fixed in $10 \%$ neutral formalin as fixative and sent to Cancer Institute for histopathological examination according to (Bancroft, et al., 1996).

\section{Statistical analysis:}

The obtained data were statistically analyzed using computerized SPSS (Statistic Program Sigmastat, Statistical Soft-Ware, SAS Institute, Cary, NC). Effects of different treatments were analyzed by one way ANOVA (Analysis of variance) test using Duncan's multiple range test and $\mathrm{p}<0.05$ was used to indicate significance between different groups (Snedecor and Cochran, 1967).

\section{Results and Discussion}

The rustle in Table (1) showed that the chemical composition of asparagus. Asparagus spears are highly appreciated for their chemical composition of bioactive compounds the contents of moisture, crude protein, crude fat, ash, and carbohydrates, (7.11, 8.43,6.18,5.12, and 73.16 ) 
respectively. This rustle agreed that (Jessie, 2014) who found that the water makes up $93 \%$ of asparagus's composition. Asparagus is low in calories and is very low in sodium. It is a good source of vitamin B6, calcium, magnesium and zinc, and a very good source of dietary fibre, protein beta-carotene, vitamin $\mathrm{C}$, vitamin $\mathrm{E}$, vitamin $\mathrm{K}$, thiamin, riboflavin, niacin, folic acid, iron, phosphorus, potassium, copper, manganese and selenium, ((Tranchim, et al., 2010) as well as chromium, at race mineral that enhances the ability of insulin to transport glucose from the bloodstream into cells. The amino acid asparagines get its name from asparagus, as the asparagus plant is relatively rich in this compound.

\section{Chemical composition of pan bread prepared from wheat flour with various levels of powder asparagus leaves.}

The data in Table (2) show that, the highest content of crude protein, fat and fiber were recorded in group un-fortified pan bread ( 19 . 85, 2. 68 and $1.72 \mathrm{~g} / 100 \mathrm{~g}$ ) compared to the other groups of pan bread fortification at 5\%,10\% and $15 \%$ with ASPG. On the other side the result recorded highest content of crude protein and crude fat were in group fortified pan bread with 15\% ASPG (18.14 and $2.54 \mathrm{~g} / 100 \mathrm{~g}$ ) in compared with the other groups of pan bread fortification at 5\%,10\% and $15 \%$ with ASPG. While showed that, the lowest content of carbohydrates were recorded $(36.09 \mathrm{~g} / 100 \mathrm{~g})$ compared with the other groups of pan bread fortification at 5\%,10\% and $15 \%$ with ASPG.

\section{Effect of asparagus leaves powder on the sensory attributes of the pan bread group.}

The mean scores of the sensory attributes are presented in table (3) showed that there was significant decrease in preference in all the attributes evaluated as the percentage of asparagus leaves powder increased. Most of panelists were preferred the taste and oder of pan bread made from wheat flour ( control group) and bread made from wheat flour fortified with $5 \%$ and $10 \%$ asparagus leaves powder. The commented that the taste and oder of these samples were like than bread fortified with $15 \%$ asparagus may be 
decrease in likeness for oder of the bread group could be attributed to the herbal oder of the leaves powder.

Protective effect of asparagus fortified pan bread on untritional paraneters and kikneys weight 1 body weight $\%$ of rats suffering from chronic venal failure.

Data presented in table (4) showed that significant decrease in the mean volue of food intake as well as body weight gain $\%$ of control positive group compared to control negative group. Treatment fortified pan bread (5, 10 and $15 \%$ ASPG) had the highest values of food intake compared with the positive control group .

Body weight gain $\%$ of the positive control group was significantly decreased as compared with the negative control group. The data showed that non-significant in body weight gain all other group treatment fortified pan bread (5\%, 10 and $15 \%$ ASPG). On the other side, treatment fortified pan bread in chronic renal rats with $10 \%$ ASPG showed that the significant increase in body weight gain .

As indicated in table (4) all treatment fortified pan bread with asparagus induced significant decrease in kidney weight / body weight $\%$, except $10 \%$ asparagus group as compared with the positive control group.

Protective effect of asparagus fortified pan bread on kidneys function of rats suffering from chronic renal failure.

Serum uric acid, creatinine and urea nitrogen for the groups of rats are illustrated in table (5). Form these results; it could observe that was increased significant in the positive control group compared with the negative control group.

The findings presented in this table showed that the decrease significant value of serum uric acid, creatinine and urea nitrogen all other group treatment fortified pan bread ( $5 \%, 10$ and $15 \%$ ASPG) compared with the positive control group. While the except for the group of rats treated with fortified pan bread $10 \%$ ASPG. Our results confirmed that asparagus at high concentration improved the nutritional value and realized the best effect on kidney functions. This rustle agreed with (Jagannath et 
al., 2012 and Jessie, 2014) who found that the asparagus can act as a natural diuretic. This can help ride the body of excess salt and fluid, making it especially good for people suffering from edema and high blood pressure. It also helps flush out toxins in kidneys and prevent kidney stones.

Protective effect of asparagus fortified pan bread on liver enzymes activity of rats suffering from chronic renal failure.

In table (6) liver enzymes activity of AST, ALT and ALP levels were recorded significant increased of the control negative group as well as other treated rat groups . Other treated groups with fortified bread ASPG from the high level showed that decrease significant in AST, ALT and ALP levels compared with the positive control group while the except for the group of rats treated with fortified pan bread $10 \%$ ASPG.

One study has assessed the anti-oxidative ability of asparagus racemosus on the liver of rats noted that $50 \mathrm{mg} / \mathrm{kg}$ of asparagus racemosus was able to attenuate damage induced by Isoniazid, a medication causing toxic symptoms in some patients. Isoniazid appears to induce $\mathrm{CYP}_{2} \mathrm{E}_{1}$ which mediates toxicity (Yue, 2004), and may be secondary to depletion of glutathione S-transfers (Yue, 2009). Asparagus appears to attenuate the increase in $\mathrm{CYP}_{2} \mathrm{E}_{1}$ to $86 \%$ of toxin-control yet appeared to have more significant protective effects on liver enzymes, which were reduced to increases of $40 \%$ (ALP), $21.6 \%$ (ALT), and 38.4\% (AST), assuming toxincontrol is $100 \%$ (Palanisamy et al., 2012). These were thought to be secondary to antioxidative properties of asparagus racemosus. The acute toxicity study of methanolic extract of asparagus pubescens roots was studied on rats. The indices of the study were the liver enzymes (transaminases). Cholesterol, creatinine and urea serum levels as well as the ionic analysis. Both alanine aminotransferase (ALT) and Aspartate aminotransferase (AST) showed a significant $(\mathrm{p}>0.01-0.001)$ non dosedependent increases in serum levels (Paul et al., 2004). 
Protective effect of asparagus fortified pan bread on serum lipid profile of rats suffering from chronic renal failure.

Results in table (7) indicated that there was positive control group increase significant in the serum TC, TG, LDL-c and VLDL-c. While the levels of HLDL-c significantly higher, compared to the negative control group.

Within the groups of rats treated groups fortified pan bread with different levels of ASPG at 5\%,10\%, and 15\% had the lowest significant serum TC, TG, LDL-c and VLDL-c compared to the positive control group. On the other hand, all treated groups fortified pan bread with different levels of ASPG had significantly higher of HLDL-c comparison with those of the positive control group. The best results in lipid fractions all treated groups of rats treated with fortified pan bread $10 \%$ ASPG.

( Madhavan, et al., 2010 Nalam, et al., 2014 ) reported that substitute for asparagus against cholesterol diet induced hyperlipidemic rats and tannins play a role in hypolipidemic effect of saponins precipitate cholesterol, from micelles and interfere with hepatic circulation of bile acids making it unavailable for intestinal absorption, this forces liver to produce more bile from cholesterol ( serum ).

Protective effect of asparagus fortified pan bread on glutathion, catalase and SOD activities in kidney tissue of rat from chronic renal failure .

Table (8) noticed that positive control fed on arginine diet showed a significant decrease of mean values of serum glutathion, catalase and SOD compared to the negative control group. It was significantly higher than mean values of serum glutathion, catalase and SOD. While there were significant increase of 5\%,10\% and 15\% ASPG fortified pan bread groups in in serum glutathion, catalase and SOD compared to the positive control group.

SOD and CAT are the two major scavenging enzymes that remove the toxic free radicals. SOD is the first enzyme in antioxidant defense system that protects tissueslagainst oxygen free radicals by catalyzing the 
removal of superoxide radical (02), which damages the membrane and biological structures ( Arivazh et al., 2000 ) CAT has been shown to be responsible for the detoxification of significant amounts of $\mathrm{H}_{2} \mathrm{O}_{2}$ ( Rong et al ., 2011 and Rakesh et al., 2013 ). There was a reduction in the activity serum SOD and CAT in HCD induced rats when compared to control rats, this may be due to the enhanced production of Reactive Oxygen Species ( ROS ) by hyperlipidema. This free radical affects the antioxidant activity. Treatment with asparagus restores the GSH induced alteration in the activity of CAT to near control due to its free radical scavenging activity.

According to (Bhatnagar et al., 2005) showed that the natural antioxidants such as high in vitamin $\mathrm{K}$ and folate, asparagus is extremely well balanced, even among nutrient-rich vegetables. "Asparagus is high in anti-inflammatory nutrients as well as provides a wide variety of antioxidant nutrients, including vitamin $\mathrm{C}$, beta-carotene, vitamin $\mathrm{E}$, and the minerals zinc, manganese and selenium," said San Diego-based nutritionist Laura Flores. Furthermore, the vegetable contains the amino acid asparagine, as well as chromium, a trace mineral that helps insulin do its job transporting glucose. It's also especially rich in glutathione, a detoxifying compound that can help destroy carcinogens. For this reason, asparagus may help fight or protect against certain cancers, including bone, breast, lung and colon cancers ( Rakesh et al., 2013 ).

\section{Histopathological in kidney:}

The obtained results confirmed by the histopathological examination. Kidney of normal control group (-ve) showed the normal histopathological structure of renal parenchyma (Pic.1), while kidney of positive control group (+ve) showed hypertrophy of glomerular tuft and thickening of parietal layer of bowman's capsule (Pic.2), kidney of group 3 showed atrophy of glomerular tuft and distension of bowman's space (Pic.3) while jitney of groups (4 and5) showed no histopathological changed (Pic.4 and5).

\section{Conclusions:}


It could be concluded that, asparagus these agents are known to interfere with the integrity of the liver and kidney to varying.

Table 1: Chemical composition of asparagus g/100g:

\begin{tabular}{|c|c|c|c|c|c|}
\hline \hline Sample & Moisture & Crude Protein & Crude Fat & Ash & Carbohydrates \\
\hline \hline Asparagus & 7.11 & 8.43 & 6.18 & 5.12 & 73.16 \\
\hline \hline
\end{tabular}

Each value represents the average of three determinations.

Table 2: Chemical composition of pan bread nutrients $\mathrm{g} / 100 \mathrm{~g}$.

\begin{tabular}{|c||c|c|c|c|c|c||}
\hline Sample & Moisture & $\begin{array}{c}\text { Crude } \\
\text { Protein }\end{array}$ & $\begin{array}{c}\text { Crude } \\
\text { Fat }\end{array}$ & Ash & $\begin{array}{c}\text { Crude } \\
\text { Fiber }\end{array}$ & Carbohydrates \\
\hline \hline $\begin{array}{c}\text { Un-fortified bread } \\
\text { (control) }\end{array}$ & 37.26 & 19.85 & 2.68 & 2.33 & 1.72 & 36.16 \\
\hline $\begin{array}{c}5 \% \text { ASPG fortified } \\
\text { pan bread }\end{array}$ & 38.19 & 16.25 & 2.14 & 2.95 & 1.60 & 43.65 \\
\hline $\begin{array}{c}10 \% \text { ASPG } \\
\text { fortified pan bread }\end{array}$ & 39.63 & 17.68 & 2.47 & 2.57 & 1.56 & 36.09 \\
\hline $\begin{array}{c}15 \% \text { ASPG } \\
\text { fortified pan bread }\end{array}$ & 31.52 & 18.14 & 2.54 & 2.63 & 1.52 & 43.65 \\
\hline \hline
\end{tabular}

Each value represents the average of three determinations.

Table 3: Sensory evaluation of asparagus fortified pan bread.

\begin{tabular}{|c||c|c|c|c|c|c|c||}
\hline Samples & $\begin{array}{c}\text { Appearan } \\
\text { ce (20) }\end{array}$ & $\begin{array}{c}\text { Taste } \\
(\mathbf{1 5})\end{array}$ & $\begin{array}{c}\text { Odor } \\
(\mathbf{1 0})\end{array}$ & $\begin{array}{c}\text { Crumb } \\
\mathbf{c o l o r} \\
(\mathbf{1 0})\end{array}$ & $\begin{array}{c}\text { Volum } \\
\mathbf{e}(\mathbf{1 5})\end{array}$ & $\begin{array}{c}\text { Texture } \\
(\mathbf{1 5})\end{array}$ & $\begin{array}{c}\text { Overall } \\
\text { acceptability } \\
(\mathbf{1 5})\end{array}$ \\
\hline \hline $\begin{array}{c}\text { Un-fortified bread } \\
\text { (control) }\end{array}$ & 19.0 & 14.9 & 9.11 & 9.47 & 13.33 & 14.82 & 14.28 \\
\hline $\begin{array}{c}5 \% \text { ASPG fortified } \\
\text { pan bread }\end{array}$ & 17.5 & 13.8 & 9.9 & 8.64 & 12.89 & 13.56 & 13.17 \\
\hline $\begin{array}{c}10 \% \text { ASPG } \\
\text { fortified pan bread }\end{array}$ & 16.0 & 14.0 & 8.9 & 9.33 & 12.72 & 14.02 & 14.13 \\
\hline $\begin{array}{c}15 \% \text { ASPG } \\
\text { fortified pan bread }\end{array}$ & 16.0 & 14.7 & 7.5 & 9.11 & 11.17 & 14.29 & 14.09 \\
\hline
\end{tabular}




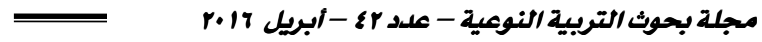

Table (4): Protective effect of asparagus fortified pan bread on nutritional parameters and kidneys weight / body weight \% of rats suffering from chronic renal failure.

\begin{tabular}{||c||c|c|c|c|c||}
\hline Parameters & $\begin{array}{c}\text { Initial } \\
\text { weight } \\
\text { (g) }\end{array}$ & $\begin{array}{c}\text { Final } \\
\text { weight } \\
\text { (g) }\end{array}$ & $\begin{array}{c}\text { Food } \\
\text { Intake } \\
\text { g/day/rat }\end{array}$ & $\begin{array}{c}\text { Body } \\
\text { weight } \\
\text { gain } \\
\text { \% }\end{array}$ & $\begin{array}{c}\text { Kidneys } \\
\text { weight/ } \\
\text { body weight } \\
\%\end{array}$ \\
\hline \hline Normal control group & $104.70 \pm$ & $129.70 \pm$ & $15.667 \pm$ & $25.359 \pm$ & $0.603 \pm$ \\
& $21.36 \mathrm{a}$ & $29.36 \mathrm{a}$ & $0.817 \mathrm{a}$ & $1.549 \mathrm{a}$ & $0.013 \mathrm{e}$ \\
\hline Positive control group & $104.80 \pm$ & $111.35 \pm$ & $13.383 \pm$ & $7.616 \pm$ & $1.253 \pm$ \\
& $16.65 \mathrm{a}$ & $35.65 \mathrm{a}$ & $0.585 \mathrm{c}$ & $0.971 \mathrm{~d}$ & $0.083 \mathrm{a}$ \\
\hline $5 \%$ ASPG fortified pan & $104.70 \pm$ & $131.30 \pm$ & $14.667 \pm$ & $27.988 \pm$ & $1.054 \pm$ \\
bread & $10.88 \mathrm{a}$ & $22.30 \mathrm{a}$ & $0.605 \mathrm{~b}$ & $1.496 \mathrm{~b}$ & $0.102 \mathrm{c}$ \\
\hline $10 \%$ ASPG fortified & $105.00 \pm$ & $131.12 \pm$ & $14.750 \pm$ & $26.523 \pm$ & $0.943 \pm$ \\
pan bread & $12.90 \mathrm{a}$ & $21.26 \mathrm{a}$ & $0.758 \mathrm{~b}$ & $1.246 \mathrm{~b}$ & $0.086 \mathrm{~d}$ \\
\hline $15 \%$ ASP fortified pan & $105.00 \pm$ & $135.19 \pm$ & $14.517 \pm$ & $30.303 \pm$ & $1.117 \pm$ \\
bread & $18.34 \mathrm{a}$ & $23.34 \mathrm{a}$ & $0.615 \mathrm{~b}$ & $0.995 \mathrm{bc}$ & $0.094 \mathrm{bc}$ \\
\hline
\end{tabular}

Mean values in each column having different superscript (a, b, c, d ,e) are significant. Means with the same letter are insignificantly different.

Table (5): Protective effect of asparagus fortified pan bread on kidneys function of rats suffering from chronic renal failure.

\begin{tabular}{|c|c|c|c|}
\hline $\mathrm{C}_{\text {Groups }}$ Parameters & $\begin{array}{c}\text { Uric acid } \\
\mathrm{mg} / \mathrm{dl}\end{array}$ & $\begin{array}{c}\text { Creatinine } \\
\text { mg/dl }\end{array}$ & $\begin{array}{c}\text { Urea } \\
\text { Nitrogen } \\
\text { mg/dl } \\
\end{array}$ \\
\hline Normal control group & $\begin{array}{l}1.49 \pm \\
0.42 \mathrm{e}\end{array}$ & $\begin{array}{l}0.54 \pm \\
0.54 \mathrm{e}\end{array}$ & $\begin{array}{c}31.99 \pm \\
2.91 \mathrm{e}\end{array}$ \\
\hline Positive control group & $\begin{array}{l}2.87 \pm \\
0.62 \mathrm{a} \\
\end{array}$ & $\begin{array}{l}4.24 \pm \\
0.47 \mathrm{a} \\
\end{array}$ & $\begin{array}{c}82.96 \pm \\
3.57 \mathrm{a} \\
\end{array}$ \\
\hline $5 \%$ ASPG fortified pan bread & $\begin{array}{l}2.15 \pm \\
0.14 \mathrm{c}\end{array}$ & $\begin{array}{l}2.85 \pm \\
0.13 \mathrm{c}\end{array}$ & $\begin{array}{l}63.90 \pm \\
2.38 \mathrm{c} \\
\end{array}$ \\
\hline $\begin{array}{l}10 \% \text { ASPG fortified pan } \\
\text { bread }\end{array}$ & $\begin{array}{l}1.91 \pm \\
0.16 \mathrm{~d}\end{array}$ & $\begin{array}{l}2.35 \pm \\
0.17 \mathrm{~d}\end{array}$ & $\begin{array}{l}52.39 \pm \\
4.48 \mathrm{~d} \\
\end{array}$ \\
\hline $15 \% \quad$ ASP fortified pan bread & $\begin{array}{l}2.51 \pm \\
0.70 \mathrm{~b}\end{array}$ & $\begin{array}{l}3.13 \pm \\
0.25 \mathrm{~b}\end{array}$ & $\begin{array}{l}72.21 \pm \\
3.38 \mathrm{~b}\end{array}$ \\
\hline
\end{tabular}

Mean values in each column having different superscript (a, b, c, d ,e) are significant. Means with the same letter are insignificantly different. 
Table (6): Protective effect of asparagus fortified pan bread on liver enzymes activity of rats suffering from chronic renal failure

\begin{tabular}{|c|c|c|c|}
\hline $\begin{array}{ll} & \text { Parameters } \\
\text { Groups } & \\
\end{array}$ & $\begin{array}{l}\text { AST } \\
(\mathbf{I u} / \mathbf{l})\end{array}$ & $\begin{array}{l}\text { ALT } \\
(\mathbf{I u} / \mathbf{l}) \\
\end{array}$ & $\begin{array}{l}\text { ALP } \\
(\mathbf{I u} / \mathbf{l}) \\
\end{array}$ \\
\hline Normal control group & $\begin{array}{l}53.80 \\
\pm 2.11 \mathrm{e}\end{array}$ & $\begin{array}{l}25.21 \pm \\
1.78 \mathrm{e}\end{array}$ & $\begin{array}{l}66.26 \pm \\
3.97 \mathrm{e}\end{array}$ \\
\hline Positive control group & $\begin{array}{c}93.57 \pm \\
5.58 \mathrm{a}\end{array}$ & $\begin{array}{l}52.86 \pm \\
3.27 \mathrm{a}\end{array}$ & $\begin{array}{c}114.39 \pm \\
6.49 \mathrm{a}\end{array}$ \\
\hline $5 \%$ ASPG fortified bread & $\begin{array}{l}71.86 \pm \\
4.75 \mathrm{bc}\end{array}$ & $\begin{array}{l}41.76 \pm \\
3.13 \mathrm{~cd}\end{array}$ & $\begin{array}{l}90.33 \pm \\
3.65 \mathrm{bc}\end{array}$ \\
\hline $10 \%$ ASPG fortified pan bread & $\begin{array}{l}69.08 \pm \\
4.28 \mathrm{~d}\end{array}$ & $\begin{array}{c}34.83 \pm \\
3.43 \mathrm{e}\end{array}$ & $\begin{array}{l}76.764 \pm \\
5.649 \mathrm{~d}\end{array}$ \\
\hline $15 \%$ ASPG fortified pan bread & $\begin{array}{l}76.82 \pm \\
3.02 \mathrm{~b}\end{array}$ & $\begin{array}{l}40.73 \pm \\
2.14 \mathrm{bc}\end{array}$ & $\begin{array}{l}92.896 \pm \\
2.622 b\end{array}$ \\
\hline
\end{tabular}

Mean values in each column having different superscript (a, b, c, d ,e) are significant. Means with the same letter are insignificantly different.

Table (7): Protective effect of asparagus fortified pan bread on serum lipid profile of rats suffering from chronic renal failure

\begin{tabular}{|c|c|c|c|c|c|}
\hline 7 & $\begin{array}{c}\mathrm{TC} \\
\mathrm{mg} / \mathrm{dl}\end{array}$ & $\begin{array}{c}\text { TG } \\
\mathrm{mg} / \mathrm{dl}\end{array}$ & $\begin{array}{l}\text { LDL-c } \\
\mathrm{mg} / \mathrm{dl}\end{array}$ & $\begin{array}{l}\text { HDL-c } \\
\mathrm{mg} / \mathrm{dl}\end{array}$ & $\begin{array}{c}\text { VLDL-c } \\
\mathrm{mg} / \mathrm{dl}\end{array}$ \\
\hline Norm & $\begin{array}{c}15.49 \pm \\
3.86 \mathrm{e}\end{array}$ & $\begin{array}{r}45.16 \\
\pm 2.28 \mathrm{e} \\
\end{array}$ & $\pm 0.71 \mathrm{e}$ & $\begin{array}{r}48.30 \\
\pm 2.25 \mathrm{a} \\
\end{array}$ & $\begin{array}{r}9.027 \\
\pm 0.457 \mathrm{e} \\
\end{array}$ \\
\hline $\mathrm{P}$ & $\begin{array}{r}125.46 \\
\pm 3.84 \mathrm{a} \\
\end{array}$ & $\begin{array}{r}75.43 \\
\pm 4.15 \mathrm{a} \\
\end{array}$ & $\begin{array}{r}84.77 \\
\pm 1.18 \mathrm{a} \\
\end{array}$ & $\begin{array}{c}26.21 \\
\pm 2.83 \mathrm{~d} \\
\end{array}$ & $\begin{array}{r}15.85 \\
\pm 0.83 \mathrm{a} \\
\end{array}$ \\
\hline $\begin{array}{l}5 \% \text { ASPG fortified pan } \\
\text { bread } \\
\end{array}$ & $\begin{array}{r}105.48 \\
\pm 4.28 \mathrm{c} \\
\end{array}$ & $\begin{array}{r}64.324 \\
\pm 3.083 \mathrm{bc} \\
\end{array}$ & $\begin{array}{c}59.58 \pm \\
1.76 \mathrm{c} \\
\end{array}$ & $\begin{array}{r}33.02 \\
\pm 2.76 \mathrm{c} \\
\end{array}$ & $\begin{array}{r}12.84 \\
\pm 0.61 \mathrm{bc} \\
\end{array}$ \\
\hline $\begin{array}{c}10 \% \text { ASPG fortified pan } \\
\text { bread }\end{array}$ & \begin{tabular}{|r|}
89.27 \\
$\pm 4.54 \mathrm{~d}$ \\
\end{tabular} & $\begin{array}{r}51.194 \\
\pm 3.456 \mathrm{~d} \\
\end{array}$ & $\begin{array}{r}42.06 \\
\pm 0.37 \mathrm{~d} \\
\end{array}$ & $\begin{array}{r}36.97 \\
\pm 2.75 \mathrm{~b} \\
\end{array}$ & $\begin{array}{r}10.29 \\
\pm 0.62 \mathrm{~d} \\
\end{array}$ \\
\hline $\begin{array}{cc}15 \% & \begin{array}{c}\text { ASPG fortified pan } \\
\text { bread }\end{array} \\
\end{array}$ & $\begin{array}{r}111.14 \\
\pm 3.65 \mathrm{~b} \\
\end{array}$ & $\begin{array}{r}67.188 \\
\pm 2.795 \mathrm{~b} \\
\end{array}$ & $\begin{array}{c}65.76 \pm \\
2.36 \mathrm{~b} \\
\end{array}$ & $\begin{array}{r}32.60 \\
\pm 1.74 \mathrm{c} \\
\end{array}$ & $\begin{array}{r}13.48 \\
\pm 0.59 \mathrm{~b} \\
\end{array}$ \\
\hline
\end{tabular}

Mean values in each column having different superscript (a, b, c, d ,e) are significant. Means with the same letter are insignificantly different. 


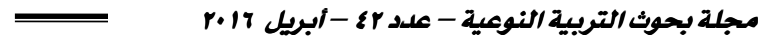

Table (8): Protective effect of asparagus fortified pan bread on glutathione, catalase and SOD activities in kidney tissue of rats suffering from chronic renal failure

\begin{tabular}{|c|c|c|c|}
\hline Groups & $\begin{array}{c}\text { Glutathione } \\
(\mathrm{mg} / \mathrm{dl})\end{array}$ & $\begin{array}{c}\text { Catalase } \\
(\mathbf{u} / \mathbf{l}) \\
\end{array}$ & $\begin{array}{r}\text { SOD } \\
\mathbf{U} / \mathbf{m L} \\
\end{array}$ \\
\hline Normal control & $\begin{array}{c}21.43 \pm \\
2.52 \mathrm{a} \\
\end{array}$ & $\begin{array}{c}385.21 \pm \\
55.14 \mathrm{a} \\
\end{array}$ & $\begin{array}{c}452.02 \pm \\
8.0 \mathrm{a} \\
\end{array}$ \\
\hline Positive control group & $\begin{array}{l}9.52 \pm \\
1.14 \mathrm{~d}\end{array}$ & $\begin{array}{l}115.55 \pm \\
10.14 \mathrm{~d} \\
\end{array}$ & $\begin{array}{c}341.50 \pm \\
10.32 \mathrm{e} \\
\end{array}$ \\
\hline $\begin{array}{c}5 \% \text { ASPG fortified pan } \\
\text { bread }\end{array}$ & $\begin{array}{l}15.49 \pm \\
2.45 \mathrm{c}\end{array}$ & $\begin{array}{c}244.77 \pm \\
32.11 \mathrm{c}\end{array}$ & $\begin{array}{c}449.81 \pm \\
19.64 b\end{array}$ \\
\hline $\begin{array}{c}10 \% \text { ASPG fortified } \\
\text { pan bread }\end{array}$ & $\begin{array}{l}17.98 \pm \\
1.49 \mathrm{~b} \\
\end{array}$ & $\begin{array}{l}291.61 \pm \\
31.61 \mathrm{~b} \\
\end{array}$ & $\begin{array}{c}441.25 \pm \\
28.3 \mathrm{~d} \\
\end{array}$ \\
\hline $\begin{array}{c}15 \% \text { ASPG fortified } \\
\text { pan bread }\end{array}$ & $\begin{array}{l}16.53 \pm \\
1.94 \mathrm{~b}\end{array}$ & $\begin{array}{l}277.11 \pm \\
30.91 \mathrm{~b}\end{array}$ & $\begin{array}{c}443.25 \pm \\
18.3 \mathrm{c}\end{array}$ \\
\hline
\end{tabular}

Mean values in each column having different superscript (a, b, c, d ,e) are significant.

Means with the same letter are insignificantly different. 


\section{Histopathological in kidney:}

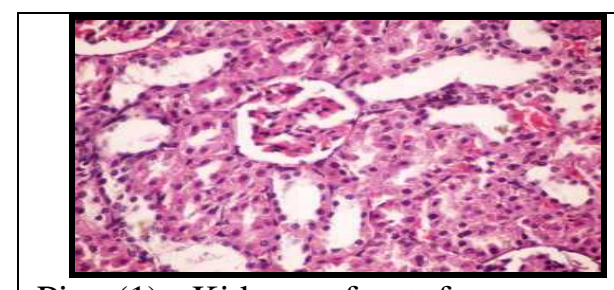

Pic. (1): Kidney of rat from control negative group showing the normal histopathological structure of renal parenchyma (H and $\mathrm{E} \times 200)$.

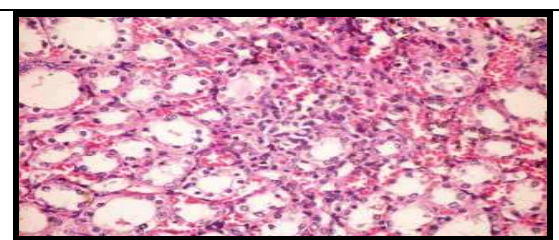

Pic. (3): Kidney of rat from groups administered $5 \%$ ASPG fortified bread showing atrophy of glomerular tuft and distension of Bowman " $\mathrm{s}$ space (H and E X400).

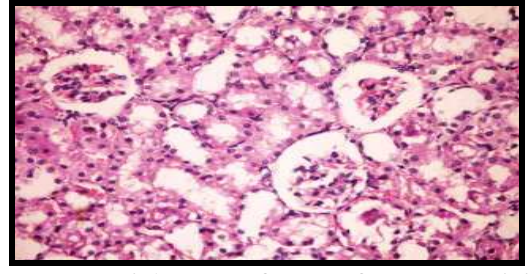

Pic.(2): Kidney of rat from positive control group showing hypertrophy of glomerular tuft and thickening of parietal layer of Bowman"s capsule (H and E X400)

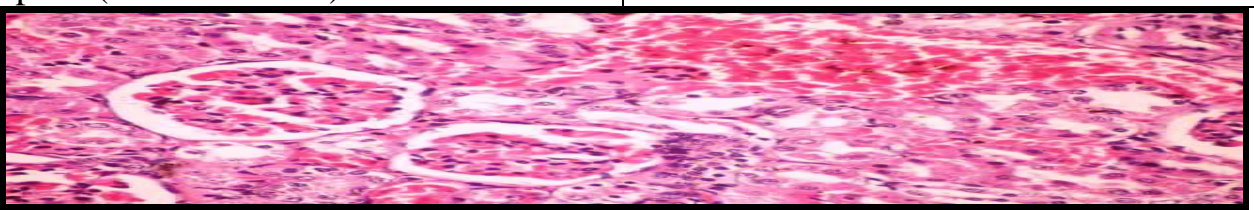

Pic. (5): Kidney of rat from group administered $15 \%$ ASPG fortified bread showing no histopathological changes (H and E X400) 


\section{REFRENCES}

- A.O.A.C. (1975). Official Methods of Analysis of Assoc. of official agricultural chemists. $12^{\text {th }}$ Ed.Washington,D.C.

- A.O.A.C. (2000). Official Methods of Analysis of tea polyphenols. Mol. Nutr. and Food Res.,

- A.O.A.C. (2002). International. 17th ed., Gaithersburg, Maryland, USA. Chap. 4. pp: 21-39.

- Allian,C.; Poon, L.; Chan, C. and Richmond, W. (1974). Enzymatic determination of total serum cholesterol . Clin. Chem., 20: 470.

- Arivazhagan P , Thilagavathy T, Panneerselvam C.(2000) . Antioxidant lipoate and tissue antioxidants in aged rats. J. Nutr. Biochem. 2 (1):19-27.

- Asparagus officinalis (2010) . Flora Europaea . Royal Botanic Garden Edinburgh. Retrieved 19 May.

- Bancroft, J., Stevens, A. and Turner, D. (1996) - Theory and practice of histological technique .4th Ed, New York, Churchill, Livingstone

- Beuchamp, C. and J. Fridovich (1971). Superoxide dismutase. Improved assay an assyapplicable to acryloamide gels. Anal Biochem. 44: 276-287.

- Bhatnagar , M., Sisodia, S.S., and Bhatnagar, R. (2005 ) : Antiulcer and antioxidant activity of Asparagus recemosus willd and withania somnifera Dunal in rats. 1056:261-78.

- Bohmer, H. B. U. M. (1971). Micro-determination of creatinine. Clin.Chem. Acta.; 32: 81-85.

- Bopana, N., and Saxena, S.(2007). Asparagus racemosus ethnopharmacological evaluation and conservation needs. J Ethnopharmacol. 110:1-15.

- Carrasco-Pozo, C., Mizgier, M.L., Speisky, H., and Gottel M, (2012). Differential protective effects of quercetin, resveratrol, rutin and epigallocatechin gallate against mitochondrial dysfunction induced by indomethacin in Caco-2 cells. Chem Biol Interact . 195:199-205.

- Deli, J.,Matus, Z., and Toth, G.(2000). Carotenoid composition in the fruits of Asparagus officinalis. J Agric Food Chem. 48:2793-6. 
- Dewettinck, K., F. Van Bockstaele, B. Kuhne, D. Van de Walle, T. and Courtens, X. Gellynck, (2008). Nutritional value of bread: Influence of processing, food interaction and consumer perception. Journal of Cereal Science, 48: 243-257.

- Elias, E. (2011). Jaundica. In : Oxford Texthbook of Medicine. Edition . Oxford University.

- Ellman, G.L. (1958): Liver glutathione. A colorimetric method for determining low concentration of glutathione. Arch Biochem Biophys 78: 443-450.

- Farnsworth, N.R., Bingel, A.S., Soejarto, D.D., Wijesekera, R.O.B., and Perea- Sasiain, J. (1991).Prospects for higher plants as a source of useful fertility-regulating agents for human use. Symposium on recent advances in fertility regulation. BEIJING,2-5 September, 1980 pp.

- Fossati, P.; Prencipe, L. and Berti, G. (1980). Enzymatic colorimetric method of determination of uric acid in serum. Clin. Chem.; 26 (2): 227- 273.

- Fossati, P. and Principe, L. (1982). Serum triglycerides determined calorimetrically with an enzyme that produces hydrogen peroxide. Clin. Chem., 28(10): 2077-2080.

- Friedewald, W.T.; Levy, R.I. and Fredrickson, D.S.(1972). Determentation of high density lipoprotein cholesterol by selective precipitation. Clin. Chem., 18:499-502.

- Grubben, G.J.H., and Denton, O.A.(2004). Plant Resources of Tropical 2. Vegatables. PROTA Foundation,Wageningen; Backhuys, Leiden; CTA, Wageningen.

- Jagannath N. (2012). Study of antiurolithiatic activity of Asparagus racemosus on albino rats. Indian J Pharmacol. 33-45.

- Javed, H., Khan, M.M., Ahmad, A., Vaibhav, K., Ahmad, M.E., Khan, A., Rutin (2012). prevents cognitive impairments by ameliorating oxidative stress and neuroinflammation in rat model of sporadic dementia of Alzheimer type. Neuroscience. 210:340-52.

- Kamalakkannan, N., and Prince, P.S.(2006). Antihyperglycaemic and Antioxidant Effect of Rutin, a polyphenolic flavonoid, in streptozotocin-induced diabetic wistar rats. Basic Clin Pharmacol Toxico. 98:97-103. 
- Kawano, K., Sakai, K., Sato, H., and Sakamura, S. A.(1975). bitter principle of asparagus: Isolation and structure of furostanol saponin in asparagus storage root. Agric Biol Chem. 39:1999-2002.

- Kind, P.R. and King, E.J. (1954). Estimation of alkaline phosphatase activity by determination of hydrolyzed phenol with aminoantipyrene. J. Clin. Path.7, 322.

- Litwinek, D., Gambuś, H., Mickowska, B.,. Zięć, G., and Berski, W. (2013). Amino acids composition of proteins in wheat and oat flours used in breads production. Journal of Microbiology, Biotechnology Food Sciences: 2 (Special issue on BQRMF) 1725-1733.

- Maeda, T. Kakuta, H.,Sonoda, T., Motoki, S., Ueno, R., and Suzuki, T., (2005). Antioxidation capacities of extracts from green, purple, and white asparagus spears related to polyphenol concentration. HortScience. 40:1221-4.

- Molander, A.I. (1960). Discernment of primary taste substances and probable . Ability to judge food, Iowa State University, Pub, U.S.A.

- Nallam Jahnavi, Prasad, P.,Naidu, Koteswara, R.A.O and karunasree, C.P. (2014). Anthihyperlipidemic effect of Asparagus gonoclados baker against cholesterol diet induced hyperlipidemia in rats. Asian Journal of pharmaceutical and clinical research. Vol 7 , Suppl2.

- Negi , J.S., Singh , P., Joshi, G.P., Rawat, M.S. and Bisht, V.K. (2010). Chemical constituents of Asparagus .4 (8) :215-220.

- Palanisamy, N. and Manian, S. (2012). Protective effects of Asparagus racemosus on oxidative damage in isoniazid - induced hepatotoxic rats: an in vive study. Toxicol Ind Health.

- Panchal, S.K., Poudyal, H., Arumugam, T.V.,Browen, L.(2001). attenuates metabolic changes, nonalcoholic steatohepatitis, and cardiovascular remodeling in high-carbohydrate, high-fat diet-fedrats. J Nutr. 141:1062-9.

- Patton, C. J. and Crouch, S. R. (1977). Enzymatic calorimetric method to determine urea in serum. Anal. Chem.; 49: 464-469.

- Paul, A., Nwafora, T.W., Jacksb and longeb, O.O. (2004). Acute Toxicity study of methanolic extract of Asparagus pubescens Root in rats. African Journal of Biomedical research, vol.7 (19-21). 
- Pothuang, B., Meeploy, M., Giwanon, R., Benmart, Y., Kaewduang, M., Supatanakul, W.(2008). Biological activities of Asparagus racemosus . Afr J Tradit Complement Alternat Med . 5:230-7.

- Rakesh, K. Sindhu, E., and Sandeep Arora. (2013). Free radical scavenging and antioxidant potential of Ficus lacor buch. Hum, Asian J pharm Clin Res, 2013:6:184-186.

- Reeves, P. G.; Nielsen, F. H. and Fahmy, G. C. (1993). Reported of the American Institute of Nutrition adhoc wriling committee on the reformulation of the AIN-76 A Rodent diet. J. Nutr.; 123:1939-1951.

- Reitman, S. and Frankel, S. (1957). Determination of glutamate pyruvate transferase. Am. J. Clin. Path.; 28:56.

- Roeschlau, P.; Bernt, E. and Gruber, W. (1974). Enzymatic colorimetric test with lipid clearing factor (LCF) .J. Clin.Chem. \& Clin. Biochem., 12:403-408.

- Rony, K.A., John Mathew, Neen, P.P., and Janardhanan, K.K.(2011). Ganodermalucidum ( Fr. ) p.Karst occurring in south india attenuates gastric ulceration in rats. Ind JNot Prod Res. 2 (1) : 19-27.

- Shao, Y. , Poobrasert, O., Kennelly, E.J., Chin, C.K. , Ho, C.T., and Huang, M.T.(1997). Steroidal saponins from Asparagus officinalis and their cytotoxic activity . Planta Med. 63:258-62.

- $\quad$ Snedecor, G.W. and Cochran, W.G. (1967). Statistical Methods. $7^{\text {th }}$ Ed., The Lowa State University Press., Ames, Lowa, U.S.A.

- Tranchim, S., Brouant, P., and Iacazio, G.(2010). The rutin catabolic pathway with special emphasis on quercetinase. Biodegradation. 21:833-59.

- Uchiyama, M., and Mihara, M. (1978). Determination of malondialdhyde precursor in tissues by thiobarbituric acid test. Anal. Biochem.,86 (1),271-278.

- Ueno, K., Onodera, S., Kawakami, A., Yoshida, M, Shiomi, N.(2005). Molecular characterization and expression of a cDNA encodingg fructan: Fructan 6G fructosyitransferase from asparagus (Asparagus officinalis). New Phytol. 165:813-24.

- Madhavan, V. (2010). Pharmacognostical studies on the root tubers of Asparagus gonoclados. Indian journal of natural products and resources. $1: 57-62$. 


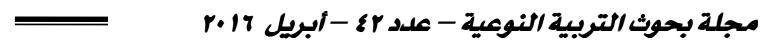

-Weiss, C., Marker, H.S. and Lehrer, G.M. (1980). Sensitive fluorometric assays for glutathione peroxidase and reductase. Anal Biochem 106: 512-516.

- Yokozawa, T.Y.; Cho, E.J. and Nakagawa, T. (2003). Influence of green tea polyphenol in rats with arginine-induced renal failure. J. Agric. Food Chem. 51:2421-2425.

- Yue J, (2004). Cyp2E1 mediated isoniazid- induced hepatotoxicity in rats. Acta Pharmacol Sin. 1220-1243.

- Yue, J. (2009). Effects of rifampin on Cyp2e1- dependent hepatotoxicity of isoniazid in rats. Pharmacal Res. 


\section{تأثير الخبز المدعم بالهيليون على اختلال وظائف الكلى في فئران التجارب} رحاب ابراهيم تاج|الدين*

$$
\text { الملخص العرببي }
$$

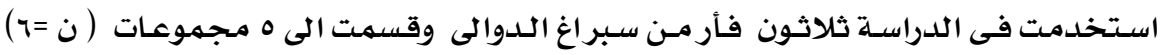
المجموعة الأولى المجموعة الكنترول الموجبـة التى تغذت على الوجبـة القياسيـة ـ أمـا المجموعـات الأربعـة

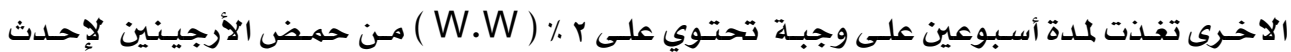

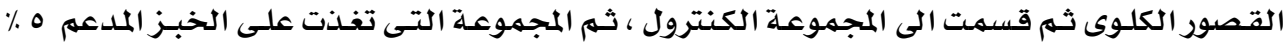
الهليون ، و الخبز المدعم ، 1 ٪ الهليون ، ثم الخبز المدعم 10 \% الهليون .

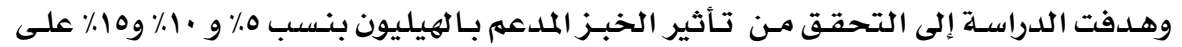
مستويات بعض القياسـات البيوكيميائيـة لكلا من وظائف الكلى ، الكبـد ، ومسستوى الدهون فى اللدم

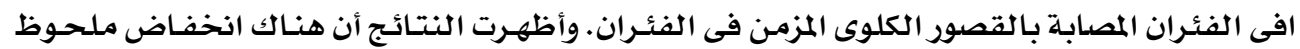
فى مستوى حمض الوريك ، الكريـاتينين ونيتروجـين ، وكذلك اليوريا . وأيضا لوحظ انخفـاض فى مستويات ALP ، ALT ، AST مقارنة بالمجموعة الضابطة الموجبة . وكشفت النتائج أن المجموعة الضـابطة الموجبـة أظهرت ارتفـاع ملحسوظ فى مستوى الدهون

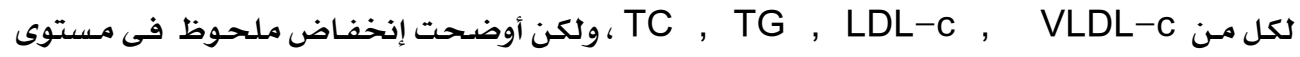

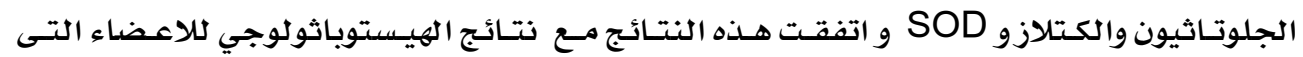

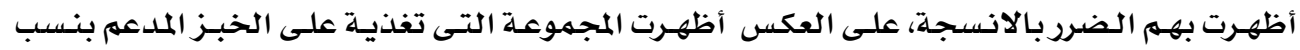

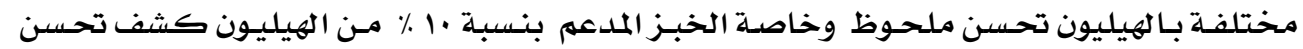

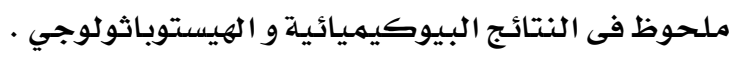

